\title{
Percepcja ryzyka w działalności przedsiębiorstw społecznych - badanie porównawcze Polska-Hiszpania ${ }^{1}$
}

\author{
Martyna Wronka-Pośpiech*, Aldona Frączkiewicz-Wronka**, Monika Tkacz***, \\ Saioa Arando****
}

Streszczenie: Przedsiębiorstwa społeczne z uwagi na tworzenie ich przez osoby z grup defaworyzowanych wpisują się w innowacyjny sposób rozwiązywania problemów społecznych. Celem opracowania jest identyfikacja i hierarchiczne przedstawienie czynników ryzyka dla działalności przedsiębiorstw społecznych. Do badania wykorzystano kwestionariusz ankiety zawierający 26 czynników ryzyka, skierowany do zarządzających w przedsiębiorstwach społecznych w Polsce (160) i Hiszpanii (158). Uzyskane wyniki badań pozwoliły na interpretację różnic w postrzeganiu ryzyk oraz ich przyczyn, co jest kluczowe w ocenie problemów pojawiających się w otoczeniu organizacji i wpływa na osiąganie pożądanych rezultatów. W okresie dynamicznego, ale też i nieco chaotycznego, rozwoju tematyki przedsiębiorczości społecznej w Polsce zaproponowana perspektywa międzykulturowa sprzyja procesowi dyfuzji wiedzy w konsekwencji analizy kontekstu międzykulturowego.

Słowa kluczowe: ryzyko, usługi społeczne, przedsiębiorstwo społeczne, spółdzielnia socjalna, Mondragon.

\section{Wprowadzenie}

Miejsce usług społecznych w systemie społeczno-gospodarczym państwa jest konsekwencją przyjętych zasad polityki społecznej. Rozwój koncepcji polityki społecznej, a szczególnie podążanie w działaniach praktycznych ku wprowadzaniu rozwiązań typowych dla aktywnej i inwestycyjnej polityki społecznej, wpłynąłna poszukiwanie nowych sposobów dostarczania usług społecznych [Grewiński, Karwacki, 2015], czego wyrazem jest między innymi tworzenie i rozwój podmiotów ekonomii społecznej. Podmioty ekonomii społecznej są naturalną organizacyjną odpowiedzią na potrzebę wspierania takich rozwiązań, których dążeniem nadrzędnym

\footnotetext{
Artykuł sfinansowany z projektu badawczego pt. Partycypacja publiczna w praktyce zarzadzania publicznego, finansowanego z działalności statutowej Uniwersytetu Ekonomicznego w Katowicach w części dotyczącej potencjału badawczego Wydziału Ekonomii w latach 2015-2017.
}

* Martyna Wronka-Pośpiech Katedra Przedsiębiorczości i Zarządzania Innowacyjnego Uniwersytet Ekonomiczny w Katowicach ul. 1 Maja 50, 40-287 Katowice e-mail: martyna.wronka@ue.katowice.pl

** Aldona Frączkiewicz-Wronka Katedra Zarządzania Publicznego i Nauk Społecznych

Uniwersytet Ekonomiczny w Katowicach ul. 1 Maja 47, 40-287 Katowice e-mail: aldona.fraczkiewicz-wronka@ ue.katowice.pl

*** Monika Tkacz MIK, S. Coop. Ibarra Zelaia Zelaigunea, 2, 20560 Oñati, Gipuzkoa e-mail: monika24039019@gmail.com

\section{**** Saioa Arando} MIK, S. Coop. Ibarra Zelaia Zelaigunea, 2, 20560 Oñati, Gipuzkoa e-mail: sarando@mondragon.edu 
jest realizacja celów społecznych przy jednoczesnym dbaniu o ekonomiczny zwrot z ponoszonych publicznych nakładów. Definicyjnie ekonomia społeczna (gospodarka społeczna) oznacza system przedsiębiorstw i organizacji oraz właściwych im uregulowań prawnych, mający na celu wspieranie osób zagrożonych wykluczeniem społecznym. Z punktu widzenia praktyki ekonomia społeczna stanowi pomost pomiędzy sferą prywatną i publiczną, a funkcjonujące w jej ramach przedsiębiorstwa społeczne są podmiotami o dualnej orientacji. Dualna orientacja oznacza konieczność godzenia działań rynkowych, czyli poszukiwania zysku wyrażonego w wartościach finansowych, z działaniami prospołecznymi wyrażającymi się zatrudnianiem osób defaworyzowanych na rynku pracy i dążeniem do ich integracji ze społeczeństwem kosztem mniejszej efektywności ekonomicznej organizacji. Paradoksalnie mniejsza efektywność jednostkowa (przedsiębiorstwa społecznego) oznacza per saldo większy zysk społeczny, bowiem przyczynia się do tworzenia spójności społecznej.

Poziom i dynamika rozwoju przedsiębiorstw społecznych jest konsekwencją zarówno akceptacji i wzmacniania - przez działających w przestrzeni publicznej instytucjonalnych aktorów organizacyjnych - przejawów idei przedsiębiorczości społecznej, jak i wewnętrzną potrzebą działania pro bono niektórych przedsiębiorców. Rozwój przedsiębiorstw społecznych jest konsekwencją szerokiej akceptacji idei przedsiębiorczości społecznej. Istotą przedsiębiorczości społecznej jest dostarczanie lokalnym społecznościom korzyści w następstwie podejmowania inicjatyw ekonomicznych w warunkach ryzyka wynikającego z rywalizacji gospodarczej, z jednoczesnym braniem pod uwagę konieczności tworzenia wartości publicznej/ społecznej jako immanentnej logiki działania. Specyfika funkcjonowania przedsiębiorstw społecznych zakłada, iż w ich działalności powinny być w szczególności dowartościowane: potrzeby rozwoju, samorealizacji oraz osiągnięcia efektu ekonomicznego przez uczestników tych przedsięwzięć. Stawia to przed zarządzającymi w tych podmiotach zadania nakierowane na modyfikację już istniejącego i wypracowania przyszłego modelu zarządzania, który uwzględniałby dualny aspekt działania tak istotny w tych podmiotach. Godzenie sprzeczności na osi kontinuum: działania rynkowe z jednej strony a tworzenie wartości publicznej/społecznej z drugiej jest niezwykle trudnym zadaniem i rodzi konieczność szerszego niż dotychczas stosowania w tych podmiotach instrumentarium zarządzania strategicznego [Kurleto, 2015, s. 8081]. W konsekwencji stałych turbulencji w otoczeniu organizacji szczególnego znaczenia nabiera umiejętność identyfikowania pojawiających się ryzyk dla podejmowanej przez podmioty ekonomii społecznej działalności.

Uznając powyższe stwierdzenia za ważne autorzy opracowania postanowili skupić się na znalezieniu odpowiedzi na pytanie o hierarchię ryzyk postrzeganych jako zagrożenie dla efektywnej działalności przedsiębiorstw społecznych. Założono, iż postrzeganie ważności poszczególnych ryzyk może - z uwagi na uwarunkowania kulturowe, społeczne czy ekonomiczne - różnić się w poszczególnych krajach. Poszukując wsparcia dla postawionej tezy dokonano analizy literatury i przeprowadzono badania terenowe w Polsce i w Hiszpanii. W Polsce występują liczne bariery hamujące rozwój podmiotów ekonomii społecznej [Raport, Komisja Europejska 2015c, s. 18-20], w Hiszpanii natomiast koncept i praktyka ekonomii społecznej są wysoko rozwinięte, a region objęty badaniem (Kraj Basków) charakteryzuje się - bazując na dostępnych statystykach Ministerstwa Pracy i Polityki Społecznej z 2014 roku [Ministerio de Empleo y Seguridad Social, 2014] najwyższym poziomem rozwoju podmiotów ekonomii społecznej w Hiszpanii. Zróżnicowanie poziomu rozwoju ekonomii społecznej w badanych krajach - w opinii autorów opra- 
cowania - może stać się istotnym elementem wpływającym na możliwość wyprowadzenia konstruktywnych i cennych wniosków. Przedstawiona do oceny respondentom lista ryzyk została przygotowana w konsekwencji analizy literatury przedmiotu oraz informacji uzyskanych w trakcie wywiadów z przedsiębiorcami społecznymi. W tym miejscu należy nadmienić, iż tematyka percepcji ryzyka wśród przedsiębiorców społecznych jest słabo rozpoznana $w$ literaturze przedmiotu [Wronka-Pośpiech i inni, 2017].

Obecnie - z uwagi na charakterystykę otoczenia (burzliwe) - jednym z najważniejszych zadań zarządzania strategicznego jest tworzenie i utrzymywanie organizacji tworzących wartość dla społeczeństwa. Zadanie to staje się coraz trudniejsze wskutek globalizacji, przyspieszonego tempa zmian, a także nasilonej uwagi poświęconej osiąganiu sukcesu [Starnawska, 2016]. Organizacje świadczące usługi społeczne - a przedsiębiorstwa społeczne należą do tej właśnie grupy organizacji - rodzą się i żyją z zaspokajania interesów publicznych, a dla ich funkcjonowania niezbędne jest utrzymanie politycznej legitymizacji i - w jej następstwie - możliwości korzystania ze środków publicznych przeznaczonych na realizację założonych celów społecznych. Stąd, aby prawidłowo projektować działalność oraz minimalizować potencjalne straty, konieczna jest analiza otoczenia pod kątem ryzyk, jakie w nim się uwidaczniają.

W ostatnich latach zarządzanie ryzykiem w organizacjach świadczących usługi społeczne staje się w coraz większym stopniu zagadnieniem, które zaczyna przykuwać uwagę nie tylko praktyków, ale także teoretyków procesów zarządzania. Jednak zważywszy na fakt, że dociekania na temat zarządzania ryzykiem w tych organizacjach znajdują się dopiero w stadium rozwojowym, obszar ten nie doczekał się jeszcze gruntownej teorii. W celu jej rozwinięcia potrzebne są zatem narzędzia badawcze, które byłyby przydatne do badania reguł i rutyn zarządzania ryzy- kiem. Celna identyfikacja ryzyka, a następnie analiza i ocena potencjalnych konsekwencji, a także sama reakcja na ryzyko jest istotna ze względu na kształtowanie przyszłości społeczeństwa poprzez - pośrednio - wpływanie na jakość życia obywateli oraz - bezpośrednio - na ożywianie przedsiębiorczości w organizacjach.

Współcześnie staje się oczywiste, że procesy zarządzania ryzykiem są wielowymiarowe i mają wielorakie źródła. Wśród wielu wymienia się takie jak: strategia, finanse, kontrola wewnętrzna i audyt, zarządzanie strategiczne i operacyjne, zarządzanie zasobami ludzkimi, relacje $z$ interesariuszami i inne. Zarządzanie ryzykiem oznacza skoncentrowanie uwagi na tych głównych aktywnościach podejmowanych przez organizację, które prowadzą do uzyskania przewagi konkurencyjnej oraz do takiego długofalowego rozwoju organizacji, który będzie przynosił organizacji zadowalające efekty. Zgodnie z przyjętym przez autorów opracowania założeniem, zarządzanie ryzykiem w przedsiębiorstwie społecznym można postrzegać jako strategię funkcjonalną. Zaproponowane podejście wynika z analizy założeń nurtu ofensywnego $w$ definiowaniu ryzyka [Drucker, 1964; Arrow, 1971; Grzybowski, 1974; 1991; 1994; 1995], zgodnie z którym immanentną cechą sukcesu organizacji w tym wypadku przedsiębiorstwa społecznego - jest skuteczne zarządzanie ryzykiem. Takie założenie oznacza, że należy je identyfikować, analizować oraz oceniać, a następnie w sposób właściwy na nie reagować, stosując w tym celu określone metody [Carroll, 2009; Bennet i inni, 2010; Kolluru i inni, 1996]. Zaproponowany sposób myślenia jest zgodny z wyzwaniami wynikającymi z implementacji do praktyki działania organizacji świadczących usługi społeczne zasad sformułowanych w nurcie nowego zarządzania publicznego (New Public Management) [Alonso, Clifton, Diaz-Fuentes, 2015], w którym integralnym elementem stosowanych 
praktyk zarządczych w tego typu organizacjach stało się zarządzanie ryzykiem [Young, Fone, 2001; Fone, Young, 2007; Asenova i inni, 2015; Borraz, 2007; Chen, Bozeman, 2012; Drennan, McConnell, 2007; Smith, McCloskey, 1998; Smith, Carmen, Dobrea, 2006; Tworek, 2015a; Klimczak, Pikos, 2010; Klimczak, 2009; Tworek, 2015b]. Według standardu FERMA (Federation of European Risk Management Associations) zarządzanie ryzykiem chroni i zwiększa wartość podmiotu non profit, gdyż przyczynia się do realizacji celów organizacji poprzez:

1. Zapewnienie ram systemowych, dzięki którym dalsza działalność podmiotu będzie prowadzona w sposób spójny i kontrolowany.

2. Usprawnienie procesu podejmowania decyzji, planowania i określania priorytetów dzięki uzyskaniu kompleksowej wiedzy na temat działalności podmiotu, stopnia niepewności oraz szans i zagrożeń.

3. Przyczynienie się do efektywniejszego wykorzystania (alokacji) kapitału i zasobów, jakimi dysponuje podmiot.

4. Zmniejszenie niepewności w innych niż kluczowe obszarach działalności.

5. Ochronę i budowanie majątku i wizerunku podmiotu.

6. Pomoc w rozwijaniu potencjału ludzkiego oraz bazy wiedzy podmiotu.

7. Poprawę efektywności działania organizacji [A Risk Management Standard, 2004].

Pojawiające się w otoczeniu organizacji zagrożenia są ryzykiem dla skutecznego funkcjonowania przedsiębiorstwa społecznego, co oznacza konieczność zidentyfikowania, skwantyfikowania ryzyka oraz prawidłowej na nie reakcji. Identyfikacja ryzyka rozumiana jest jako rozpoznawanie źródeł powstawania konkretnych form ryzyka, jakie występują w organizacji. Analiza ryzyka rozumiana jest jako ilościowa i jakościowa jego analiza w danej organizacji, z kolei reakcja na ryzyko w praktyce sprowadza się do minimalizacji wpływu wcześniej wykrytych zagro- żeń i dotyczy bezpośrednio skutków ryzyka, z którymi organizacje muszą się uporać.

W związku z rolą, jaką w gospodarce pełni przedsiębiorca, zdolność do ponoszenia ryzyka i radzenia sobie z niepewnością jest nie tylko wymagana, ale także odgrywa ważną rolę w wyborze ścieżki zawodowej. Wymóg ten odnosi się także do przedsiębiorców społecznych, w przypadku których umiejętność ponoszenia ryzyka jest uznawana za jedną z kluczowych cech, co zresztą znajduje odzwierciedlenie w definicjach badaczy zajmujących się zjawiskiem przedsiębiorczości społecznej takich jak Leadbeater [1997], Dees [1998], Tan, Williams, Tan [2005], Peredo, McLean [2006], oraz Zahra i inni [2009]. Na poziomie organizacji poprawna identyfikacja ryzyka i reakcja na nie jest ściśle związana z przetrwaniem przedsiębiorstwa społecznego. Wynika to z jego specyficznych cech, a zwłaszcza z wyzwań związanych z angażowaniem kapitału finansowego i zasobów ludzkich. Na poziomie indywidualnym zdolność do ponoszenia ryzyka w procesie podejmowania decyzji jest także uważana za jedną z kluczowych cech przedsiębiorców społecznych [Zahra i inni, 2008; Shaw, Carter, 2007; Tan i inni, 2005; Peredo, McLean, 2006; Zahra i inni, 2009], choć ryzyko przez nich ponoszone różni się od tego, z jakim zmagają się przedsiębiorcy komercyjni. Jak wskazuje Leadbeater [1997] kluczowa jest tu kwestia reputacji i nieposzlakowanej uczciwości. Choć przedsiębiorcy społeczni ponoszą mniejsze ryzyko finansowe niż przedsiębiorcy komercyjni, to zmagają się z większym ryzykiem personalnym o charakterze niefinansowym (np. ryzyko utraty wiarygodności czy ryzyko utraty sieci kontaktów osobistych). Poza wskazanymi powyżej właściwości wynikającymi z różnic między przedsiębiorcami komercyjnymi a społecznymi, liczba badań na temat percepcji ryzyka przez przedsiębiorców społecznych [Wronka-Pośpiech i inni, 2017] czy gotowości do jego podejmowania [Hoogendoorn i inni, 2011] jest znikoma. 


\section{Kontekst międzykulturowy}

Komisja Europejska dostrzegając specyfikę ekonomii społecznej i potrzebę jej wsparcia jednoznacznie promuje kompleksowe badania nad wskazaną problematyką w kontekście międzynarodowym i porównawczym w ramach wymiany dobrych praktyk, wiedzy i doświadczenia [Raport, Komisja Europejska 2015a, s. 3]. Przejawem dowartościowania znaczenia badań nad podmiotami ekonomii społecznej, a szczególnie wpływu tych ostatnich na kształtowanie podstaw rozwoju społeczno-gospodarczego państw, jest zainicjowanie przez Komisję Europejską badań nad tą problematyką. Rezultaty prowadzonych badań zostały opublikowane w raporcie pod tytułem A map of social enetrprises and their eco-systems in Europe, w którym dokonano dogłębnego porównania organizacji i funkcjonowania podmiotów ekonomii społecznej oraz uwarunkowań i rezultatów przedsiębiorczości społecznej w krajach Europy, jak również zaproponowano modelowe ujęcie wspierającego te podmioty ekosystemu prawno-gospodarczo-społecznego [ibidem, s. 14].

Zaproponowany przez autorów niniejszego opracowania międzykulturowy kontekst badań wymaga omówienia krajowych uwarunkowań i ich wpływu na specyfikę organizacji i funkcjonowanie sektora podmiotów ekonomii społecznej i przedsiębiorstw społecznych w Polsce i w Hiszpanii. W Hiszpanii w dyskursie publicznym częściej mówi się o organizacjach trzeciego sektora, aniżeli „przedsiębiorstwach społecznych” czy „przedsiębiorczości społecznej”. Za to termin „ekonomia społeczna” jest nie tylko rozpowszechniony i rozpoznawalny, ale także uznany prawnie i szeroko przyjęty w środowisku akademickim i publicznym. Według ustawodawstwa hiszpańskiego dotyczącego ekonomii społecznej (artykuł 2, artykuł 4, Ustawa 5/2011) [Raport, Komisja Europejska, 2015b, s. 19], działalność podmiotów ekonomii spo- łecznej to przede wszystkim działalność biznesowa przedkładająca cele członków lub wspólnoty nad zysk. Dodatkowo organizacje te charakteryzują się demokratycznym i partycypacyjnym zarządzaniem, promują solidarność i sprawiedliwy podział zysków oraz zapobiegają nierównościom płci, wykluczeniu społecznemu czy bezrobociu, a także generują stałe i dobrej jakości zatrudnienie. Podmioty ekonomii społecznej w Hiszpanii to między innymi:

1. Towarzystwa wzajemnościowe (mutualities), czyli organizacje non profit oferujące usługi społeczne i ochronę społeczną dla członków organizacji.

2. Kolejną formą podmiotów ekonomii społecznej są tzw. "sociedad laboral", w których większość pracowników (51\%) posiada prawo własnościowe z uwzględnieniem zasady, że każdemu współwłaścicielowi nie przysługuje więcej niż 33,33\% całego kapitału firmy (artykuł 1, Ustawa 44/2015) [ibidem, s. 16].

3. Spółdzielnie, które są uznane za podmioty gospodarcze podlegające hiszpańskiemu prawu spółdzielczemu według ustawy 27/1999 [ibidem, s. 16], z uwzględnieniem różnic regionalnych $w$ prawie spółdzielczym modyfikowanym przez tzw. Autonomous Communities, w celu adaptacji prawa do potrzeb danego regionu. Hiszpańskie prawo spółdzielcze rozróżnia 12 typów spółdzielni, miedzy innymi: pracownicze, edukacyjne, rolnicze, ubezpieczeniowe czy zdrowotne. Ponadto, w Hiszpanii powszechne są spółdzielnie inicjatywy społecznej tzw. Social Initiative Cooperatives lub spółdzielnie integracji społecznej tzw. Social Integration Cooperatives, których głównym celem jest integracja zawodowa osób defoworyzowanych społecznie.

4. Przedsiębiorstwa społeczne, do których należą związki i fundacje oraz organizacje WISE czyli tzw. Work Integration Social Enterprises, które są zobowiązane zatrud- 
niać ponad 30\% osób społecznie defaworyzowanych przez pierwsze trzy lata działalności [ibidem, s. 17], oraz Centrum Ochrony Pracy tzw. Sheltered Employment Centres, które skupiają swoją działalność na integracji zawodowej osób niepełnosprawnych i prawnie są zobowiązane do zatrudnienia 70\% pracowników niepełnosprawnych zgodnie z Ustawą 13/1982 o Integracji Społecznej [ibidem, s. 3].

Uwzględniając powyższą charakterystykę należałoby podkreślić, że raport Komisji Europejskiej dzieli sektor ekonomii społecznej w Hiszpanii na podmioty ekonomii społecznej oraz na przedsiębiorstwa społeczne jak następuje:

- podmioty ekonomii społecznej (o charakterze rynkowym), czyli np. spółdzielnie, sociedad laboral lub towarzystwa wzajemnościowe,

- przedsiębiorstwa społeczne (o charakterze integracyjnym), czyli np. spółdzielnie inicjatywy społecznej (tzw. Social Initiative Cooperatives), WISE, związki, fundacje, centra ochrony pracy [ibidem, s. 21].

Ponadto, raport Komisji Europejskiej proponuje również podział sektora ekonomii społecznej w Hiszpanii na następujące segmenty:

- rynkowa ekonomia społeczna (tzw. market social economy) - przedsiębiorstwa charakteryzujące się autonomią oraz swobodą członkostwa, stworzone dla realizacji celów członków przedsiębiorstwa poprzez środki uzyskane z prowadzonej działalności gospodarczej (...),

- „nierynkowa” ekonomia społeczna (tzw. 'non market' social economy) - organizacje charakteryzujące się autonomią oraz swobodą członkostwa, które dostarczają usługi „nierynkowe” i których zyski (jeśli zostaną wygenerowane) nie mogą podlegać dystrybucji według agentów zaangażowanych w jego wytworzenie (...) [ibidem, s. 4].
W Polsce, odwołując się do cytowanego raportu Komisji Europejskiej, nie ma formalnej i prawnie określonej definicji ekonomii społecznej [Raport, Komisja Europejska, 2015c, s. 1-3]. W porównaniu do Hiszpanii, charakterystyka czy definicja prawna sektora ekonomii społecznej w Polsce jest bardzo ograniczona, co prawdopodobnie wpływa na niski - w przestrzeni publicznej - poziom dyfuzji konceptu, brak powszechnego zrozumienia spectrum działalności podmiotów ekonomii społecznej i stanowi barierę w ich prawidłowym rozwoju [ibidem, s. 18-20]. Przewiduje się natomiast w najbliższych latach wprowadzenie ustawy, która podejmie próbę identyfikacji typów przedsiębiorczości społecznej i określenia ekosystemu prawnego sektora ekonomii społecznej, co wraz z jasno określonymi przepisami być może wpłynie na poprawę jego rozwoju [ibidem, s. 2].

W Polsce przedsiębiorstwa społeczne zaliczane są do instytucji, które razem tworzą środowisko rozlegle i heterogeniczne, ale najczęściej utożsamiane są z tzw. trzecim sektorem. J. Defourny i P. Develtere [2009] są zdania, że aktualnie sektor gospodarki społecznej w Polsce tworzą różnorodne podmioty instytucjonalne. Definiując gospodarkę społeczną wyróżniają oni podejście prawno-instytucjonalne oraz podejście normatywne. W pierwszym, tradycyjnym podejściu wyznacza się granice gospodarki społecznej do form prawnych i instytucjonalnych, jakie przyjmują inicjatywy działające w trzecim sektorze. W drugim podejściu - normatywnym raczej nie eksponuje się typów instytucjonalnych, ale wspólne zasady, którymi kierują się różnorodne podmioty. W podejściu prawno-instytucjonalnym powołani autorzy wyróżnili trzy uniwersalne typy organizacji, które występują w większości państw, i które składają się na szeroką definicję gospodarki społecznej. Według nich sektor gospodarki społecznej tworzą: przedsięwzięcia spółdzielcze, towarzystwa wzajemnościowe oraz stowarzyszenia [Defourny, Develtere, 2008, 
s. 21-15]. Natomiast w podejściu normatywnym gospodarkę społeczną określają jako wszelkiego rodzaju działalność gospodarczą prowadzoną przez różnorodne podmioty, które w swoich normach i systemach wartości przestrzegają następujących zasad:

- przedkładanie służby członkom lub wspólnocie nad zysk,

- autonomiczne zarządzanie,

- demokratyczny proces decyzyjny,

- $\quad$ prymat ludzi i pracy nad kapitałem przy dystrybucji dochodów [ibidem, s. 24].

Jednocześnie należy zauważyć, że zjawisko ekonomii społecznej i charakterystyczne dla niej podmioty nie są czymś nowym w przestrzeni gospodarczej [Herbst, 2008]. Na gruncie polskim w okresie międzywojennym ruch spółdzielczy należał do najbardziej dynamicznych w ówczesnej Europie. Wtedy to wykształciły się i rozwinęły dwie formy, do dziś uznawane za klasyczne mechanizmy ekonomii społecznej: towarzystwa ubezpieczeń wzajemnych (TUW) oraz spółdzielnie. Chociaż w okresie gospodarki centralnie planowanej ruch spółdzielczy zaczął zanikać (czy raczej podlegał swoistej degeneracji i wypaczeniu), to w ostatnich latach nie sposób nie zauważyć renesansu instytucji ekonomii społecznej. Obecnie rozwój ruchu spółdzielczego w Polsce jest silnie związany ze zwiększeniem finansowania tego typu podmiotów w ramach unijnych środków pomocowych [Raport, Komisja Europejska, 2015c, s. 8]. Spółdzielnie socjalne w Polsce posiadają dobrze rozwiniętą strukturę prawną i podlegają prawu spółdzielczemu, odwołując się do ustawy dot. spółdzielni socjalnych z 2006 r. [Ustawa, 2006]. Prawnie, spółdzielnie socjalne to wysoko autonomiczne podmioty łączące misję społeczną z misją ekonomiczną, charakteryzujące się demokratycznym i partycypacyjnym zarządzaniem, stawiając prymat ludzi nad kapitałem. Ich głównym celem jest reintegracja zawodowa, co pozwala na korzystanie z funduszy państwowych, głów- nie $z$ dotacji z tytułu tworzenia miejsc pracy dla osób wykluczonych społecznie [Raport, Komisja Europejska, 2015c, s. 5-6].

Ciekawa próba wskazania podmiotów należących do sektora ekonomii społecznej została podjęta w Krajowym Programie Rozwoju Ekonomii Społecznej [KPRES, 2014]. Analiza wskazanego dokumentu oraz „Wieloletniego regionalnego planu działań na rzecz promocji i upowszechnienia ekonomii społecznej oraz rozwoju instytucji sektora ekonomii społecznej i jej otoczenia w województwie śląskim na lata 2012-2020" [2013, s. 17-18] pozwoliła na przygotowanie listy zaliczonych do sektora ekonomii społecznej podmiotów:

- przedsiębiorstwa społeczne (o charakterze rynkowym) - podmioty o różnym statusie prawnym, prowadzące działalność gospodarczą, które wypracowane zyski wykorzystują do osiągania celów społecznych;

- podmioty ekonomii społecznej (o charakterze integracyjnym) - podmioty prowadzące działalność z zakresu reintegracji społeczno-zawodowej, przygotowujące osoby wykluczone i zagrożone wykluczeniem społecznym (w tym szczególnie osoby niepełnosprawne) do wejścia na rynek pracy, w tym do utworzenia przedsiębiorstwa społecznego. Klienci tych podmiotów stanowią zaplecze sektora ekonomii społecznej;

- podmioty wspierające sektor ekonomii społecznej - podmioty powołane w celu wspierania przedsiębiorczości społecznej $w$ regionie lub realizujące zadania $z$ tego obszaru;

- otoczenie sektora ekonomii społecznej podmioty, które wpływają na kondycję sektora ekonomii społecznej w regionie, w tym sprzyjają jej rozwojowi.

Warto zauważyć, że potencjał podmiotów gospodarki społecznej jest jednak w Polsce w dalszym ciągu dosyć ograniczony. 


\section{Materiał i metoda}

W literaturze przedmiotu problematyka zarządzania ryzykiem w przypadku przedsiębiorstw społecznych nie jest wystarczająco rozpoznana, a przeprowadzony przegląd literatury nie wskazywał na istnienie narzędzi służących stricte ocenie ryzyka w tych podmiotach. Autorzy analizowanych publikacji piszą raczej o zarządzaniu ryzykiem przy zastosowaniu dla tego celu adekwatniej metodyki. Przykładowo Tworek i Cziura [2017] wymieniając rodzaje ryzyka prowadzenia przedsiębiorstwa społecznego postulują ich podział na wewnętrzne i zewnętrzne, a następnie proponują fazy procesu zarządzania ryzykiem w przedsiębiorstwie społecznym, na które składają się: (1) identyfikacja ryzyka² ${ }^{2}$ (2) analiza i ocena ryzyka, (3) reakcja na ryzyko, oraz (4) monitorowanie i kontrola ryzyka. Propozycje te odnoszą się jednak do zarządzania ryzykiem w konkretnym podmiocie, podczas gdy celem autorów niniejszego opracowania było określenie i zidentyfikowanie ryzyk dla działalności przedsiębiorstw społecznych sensu largo. Dlatego też realizując wskazany powyżej cel w przeprowadzonych badaniach posłużono się zmodyfikowanym kwestionariuszem zaproponowanym przez Canadian Social Enterprise Guide [Enterprising Non-Profits Program, 2005]. Zgodnie z wiedzą autorów kwestionariusz ten jest jedynym narzędziem służącym ocenie ryzyka w przedsiębiorstwach społecznych.

W pierwszym etapie omawianych w niniejszym opracowaniu wyników badań dokonano przeglądu źródłowych danych wtór-

\footnotetext{
Oprócz klasycznej listy kontrolnej przedsiębiorcy społeczni w procesie identyfikacji ryzyka mogą wykorzystać brytyjski standard zarządzania ryzykiem wskazany w opracowaniu FERMA (Federation of European Risk Management Associations), jeszcze takie metody i techniki, jak burza mózgów, przegląd dokumentacji, analizę scenariuszy, audyt i kontrole wewnętrzne, analizę niebezpieczeństw i operatywności (HAZOP), czy np. analizy biznesowe, które omawiając poszczególne obszary działalności organizacji opisują zarówno procesy wewnętrzne, jak i czynniki zewnętrzne, które mogą na te procesy wpływać.
}

nych pod kątem identyfikacji potencjalnych ryzyk występujących w działalności przedsiębiorstw społecznych. Następnie przeprowadzono wywiady z pięcioma zarządzającymi w przedsiębiorstwach społecznych, dwoma pracownikami Ośrodka Wsparcia Ekonomii Społecznej (OWES) i trzema pracownikami naukowymi profesjonalnie zajmującymi się badaniem nad prawidłowościami funkcjonowania podmiotów ekonomii społecznej. Umożliwiło to wykrycie błędów oraz niejasności przygotowanego narzędzia badawczego oraz wzbogacenie pierwotnego kwestionariusza.

Zaprezentowane poniżej wyniki badań odnoszą się do tzw. perspektywy menedżerskiej, zatem przedstawiany jest pogląd zarządzających w przedsiębiorstwach społecznych. Siłą rzeczy więc grupę docelową w badaniach terenowych stanowili przedstawiciele kadry zarządzającej najwyższego szczebla (przedsiębiorcy społeczni, menedżerowie zarządzający przedsiębiorstwami społecznymi). Wybranie zarządzających przedsiębiorstwami społecznymi jako respondentów było spowodowane tym, że użyte $w$ badaniach zmienne wymagały, aby informacje były dostarczane przez osoby, które posiadają dobrą znajomość całości funkcjonowania i rozwoju organizacji i mają wpływ na proces podejmowania decyzji.

Zmodyfikowany kwestionariusz posłużył do zebrania danych subiektywnych $w$ formie opinii respondentów i składał się $z$ listy 26 potencjalnych ryzyk $w$ działalności przedsiębiorstw społecznych, odnoszących się do czterech zasadniczych obszarów funkcjonowania organizacji (pytania 1-3 - zasoby ludzkie, 4-11 - własność, 12-19 - zobowiązania, 25-26 - przestrzeganie prawa) oraz metryczki. Respondenci udzielali odpowiedzi na pytania dotyczące potencjalnych ryzyk posługując się skalą Likerta (gdzie ocena "1" oznaczała całkowity brak zgody, a "7" - całkowite poparcie dla stwierdzenia). Do zbierania informacji zastosowano technikę CATI. 
Tabela 1. Czynniki ryzyka w przedsiębiorstwach społecznych - wyniki zbiorcze

\begin{tabular}{|c|c|c|c|c|c|}
\hline \multirow[b]{2}{*}{ Lp. } & \multirow[b]{2}{*}{ Czynniki ryzyka } & \multicolumn{2}{|c|}{ Polska } & \multicolumn{2}{|c|}{ Hiszpania } \\
\hline & & $\begin{array}{l}\text { średnia } \\
\text { ważona }\end{array}$ & $\begin{array}{c}\text { miejsce } \\
\text { w rankingu }\end{array}$ & $\begin{array}{l}\text { średnia } \\
\text { ważona }\end{array}$ & $\begin{array}{c}\text { miejsce } \\
\text { w rankingu }\end{array}$ \\
\hline 1 & Urazy i wypadki w miejscu pracy & 3,9441 & 26 & 2,5063 & 24 \\
\hline 2 & $\begin{array}{l}\text { Śmierć, odejście na emeryturę lub rezygnacja z pracy pracowników } \\
\text { kluczowych dla działania organizacji }\end{array}$ & 4,7888 & 23 & 2,5949 & 23 \\
\hline 3 & Brak zaangażowania się pracowników w działania organizacji & 6,2298 & 1 & 5,7911 & 1 \\
\hline 4 & Uszkodzenia lub zniszczenia mienia w siedzibie działania organizacji & 4,7578 & 21 & 2,8861 & 21 \\
\hline 5 & Utrata siedziby działania organizacji & 4,8509 & 15 & - & - \\
\hline 6 & $\begin{array}{l}\text { Ryzyko związane z kradzieżą sprzętów niezbędnych organizacji do } \\
\text { działania }\end{array}$ & 4,9130 & 17 & 2,8354 & 22 \\
\hline 7 & Kradzież materiałów/zasobów niezbędnych organizacji do działania & 4,8882 & 18 & 2,8987 & 19 \\
\hline 8 & Kradzież zarobionych środków pieniężnych & 5,0124 & 9 & - & - \\
\hline 9 & Utrata informacji kluczowych dla działania organizacji & 4,5342 & 25 & 4,6962 & 8 \\
\hline 10 & $\begin{array}{l}\text { Kradzież lub zagrożenie własności intelektualnej (np. imitowanie } \\
\text { naszego dobrze sprzedającego się wyrobu) }\end{array}$ & 4,8385 & 16 & 3,7785 & 14 \\
\hline 11 & Utrata dobrej reputacji i/lub wyrobionej marki & 5,7081 & 2 & 5,0380 & 6 \\
\hline 12 & Działania na szkodę klientów & 5,5342 & 7 & 4,2722 & 12 \\
\hline 13 & $\begin{array}{l}\text { Działania na szkodę podmiotów, z którymi współpracuje organizacja } \\
\text { (partnerów) }\end{array}$ & 5,1863 & 12 & 4,4747 & 10 \\
\hline 14 & $\begin{array}{l}\text { Działania na szkodę społeczności lokalnej, w której funkcjonuje } \\
\text { organizacja }\end{array}$ & 4,7640 & 22 & 3,4810 & 17 \\
\hline 15 & Odpowiedzialność ponoszona za jakość towaru/usługi & 5,5590 & 5 & 5,1709 & 5 \\
\hline 16 & Możliwość uszkodzenia mienia innych osób lub organizacji & 4,4286 & 20 & 3,3354 & 18 \\
\hline 17 & Niedotrzymanie lub naruszenie warunków umowy & 5,4783 & 4 & 4,2342 & 13 \\
\hline 18 & $\begin{array}{l}\text { Niedotrzymanie lub naruszenie warunków umowy przez podmioty, } \\
\text { z którymi współpracuje organizacja (partnerów) }\end{array}$ & 5,3292 & 8 & 4,5886 & 9 \\
\hline 19 & Utrata środków pomocowych & 5,0497 & 10 & 5,7215 & 3 \\
\hline 20 & Utrata innych dochodów systemowych dochodów np. dotacji & 5,0497 & 11 & 5,0000 & 7 \\
\hline 21 & Spadek dochodów z działalności & 5,6832 & 3 & 5,7342 & 2 \\
\hline 22 & Straty wynikające z pożaru, powodzi czy innych zdarzeń losowych & 5,1242 & 14 & 3,0190 & 19 \\
\hline 23 & Niekorzystne zmiany sytuacji na rynku (warunki rynkowe) & 5,1801 & 6 & 5,6835 & 4 \\
\hline 24 & Słaba znajomość obowiązków prawnych po stronie pracodawcy & 4,7578 & 13 & 3,9747 & 15 \\
\hline 25 & $\begin{array}{l}\text { Słaba znajomość obowiązujących przepisów prawnych (wymagań, } \\
\text { norm i standardów prowadzenia działalności) }\end{array}$ & 4,8571 & 19 & 4,2911 & 11 \\
\hline 26 & Celowe omijanie obowiązków ustawowych & 4,7888 & 24 & 3,5063 & 16 \\
\hline
\end{tabular}

Źródło: wyniki badań własnych. 
W Polsce badanie zostało przeprowadzone w przedsiębiorstwach społecznych działających w formule spółdzielni socjalnych $^{3}$ na terenie całego kraju. Próba została dobrana losowo i obejmowała 160 spółdzielni socjalnych (co równa się 19\% ogółu podmiotów tego typu), dzięki czemu formalnie spełniała kryteria reprezentatywności. Badania odbyły się w okresie od 1 maja 2015 r. do 30 czerwca 2015 r..

W Hiszpanii badanie zostało wykonane w okresie od 15 lutego do 8 kwietnia 2016 r. i objęło w szczególności prowincję Gipuzkoa w Kraju Basków, czyli region głównej siedziby kooperatywy Mondragon ${ }^{4}$ i działającego tam Mondragon Innovation \& Knowledge $(\mathrm{MiK})^{5}$. Otrzymano 158 odpowiedzi, co biorąc pod uwagę fakt, że w 2014 r. na terenie Kraju Basków zarejestrowanych było 1532 spółdzielni [Ministerio de Empleo y Seguridad Social, 2014] w porównaniu ilościowym daje $10 \%$ próby generalnej.

W tym miejscu pragniemy nadmienić, iż po wstępnym wywiadzie z ekspertami MiK dwa czynniki ryzyka obecne w ankiecie pol-

\footnotetext{
Polskie opracowania [Herbst, 2008; Ciepielewska-Kowalik i inni, 2015] wskazują, że modelem przedsiębiorstwa społecznego najbardziej zbliżonym do kryteriów zaproponowanych przez sieć badawczą EMES są właśnie spółdzielnie socjalne.

Korporacja spółdzielcza Mondragon (Mondragón Corporación Cooperativa, MCC) powstała w Kraju Basków w latach 50. XX wieku w okresie załamania gospodarczego regionu i wysokiego bezrobocia, wykazuje wiele cech wspólnych z tradycyjnymi spółdzielniami pracy. Jej misja łączy w sobie podstawowe cele typowego przedsiębiorstwa skutecznie konkurującego na rynkach międzynarodowych, z organizacją o silnym wymiarze społecznym, wykorzystującą demokratyczne metody organizacji i zarządzania, tworzącą nowe miejsca pracy, dbającą o rozwój indywidualny i zawodowy pracowników oraz angażującą się w rozwój społeczny. Obecnie Mondragon to sieć niezależnych i autonomicznych spółdzielni, uznana za lidera ruchu spółdzielczego w Europie, jedna z największych spółdzielni w Hiszpanii, niejednokrotnie wykorzystywana jako przykład dobrych praktyk w sektorze ekonomii społecznej [Szudy 2013, s. 130-131].

Mondragon Innovation \& Knowledge (MiK) to centrum badawcze należące do sieci spółdzielni Mondragon. Jego działalność skupia się między innymi na obserwacji działalności spółdzielni Mondragonu oraz na monitorowaniu i diagnozowaniu przedsiębiorczości społecznej.
}

skiej w hiszpańskiej modyfikacji zostały pominięte. Podczas gdy w Polsce lokale spółdzielni należą bądź mogą należeć do gminy, spółdzielnie hiszpańskie posiadają siedziby własnościowe, a utrata takiej siedziby mogłaby być następstwem np. bankructwa spółdzielni (stąd eliminacja czynnika numer 5 - utrata siedziby działania organizacji). Ponadto, badane podmioty to z reguły wysoko rozwinięte spółdzielnie bądź też sieci spółdzielni, gdzie bezpośredni dostęp do zarobionych środków przez indywidulanych pracowników jest ograniczony, a sama kradzież została oceniona przez ekspertów jako niemożliwa (stąd eliminacja czynnika numer 8 - kradzież zarobionych środków pieniężnych).

W tabeli 1. przedstawiono wyniki dla wszystkich 26 czynników ryzyka, z których 10 kluczowych dla Polski i Hiszpanii zostało zinterpretowanych w kolejnej części artykułu.

\section{Identyfikacja i interpretacja czynników ryzyka w przedsiębiorstwach społecznych na przykładzie spółdzielni socjalnych - wyniki badań empirycznych w Polsce i Hiszpanii}

Analiza ogólnej oceny znaczenia ryzyk w działalności przedsiębiorstw społecznych (liczona jako średnia z oceny każdego z badanych elementów) pozwoliła na zidentyfikowanie i opisanie dziesięciu czynników traktowanych przez respondentów jako najbardziej istotne dla funkcjonowania organizacji. W tabeli 2 przedstawiono średnie ważone dla zmiennych objętych badaniem w Polsce.

Analiza ogólnej oceny znaczenia ryzyk w działalności przedsiębiorstw społecznych wykazała, że jako największe ryzyko polscy respondenci wskazują brak zaangażowania się pracowników w działania organizacji (średnia 6,2298). Znaczenie tego czynnika dla każdej organizacji jest duże, aczkolwiek w przypadku przedsiębiorstw społecznych czynnik 
ten jest szczególnie istotny z uwagi na cechy społeczno-ekonomiczne osób zatrudnionych. Zdarza się, że z uwagi na swoją sytuację osoby zmarginalizowane bądź zagrożone marginalizacją napotykają na utrudnienia w funkcjonowaniu na rynku pracy wynikające przykładowo z: niepełnych kwalifikacje zawodowych, niechęci do stałej pracy i do pełnego angażowania się w powierzone zadania, niskiej skłonności do poszerzania kwalifikacji, potencjalnie wysokiej chorobowości i absencji oraz niskiej dyscypliny [Tworek, 2014, s. 832; Haltiwanger i inni, 2010]. Aby minimalizować związane z tym czynnikiem ryzyko, zarządzający przedsiębiorstwem społecznym powinien posiadać rozwinięte kompetencje społeczne polegające na umiejętności współpracy w środowisku wielokulturowym i zarządzaniu różnorodnością [Lipka, 2002]. Właściwie zarządzanie zatrudnionymi leży w interesie każdego przedsiębiorstwa, albowiem w długiej perspektywie to właśnie zasoby w postaci lojalnej i kompetentnej kadry są kluczowym czynnikiem sukcesu. Ponieważ znaczna większość spółdzielni socjalnych zajmuje się świadczeniem różnorodnych usług (np. gastronomicznych, porządkowych, opiekuńczych i innych), to właśnie personel stanowi pierwsze i często jedyne źródło wizerunku organizacji budowanego wśród różnych odbiorców (klientów, beneficjentów itd.), a jego odbiór przyczynia się do wzrostu albo spadku rentowności przedsiębiorstwa.

Drugim co do znaczenia czynnikiem ryzyka w opinii respondentów jest utrata dobrej reputacji i/lub wyrobionej marki (średnia 5,7081). Wybór tego czynnika można tłumaczyć tym, że sukces organizacji nienastawionych na zysk jest często konsekwencją tego, jak organizacja jest postrzegana w przestrzeni publicznej. Efektywność działań przedsiębiorstw społecznych jest często finansowo niemierzalna, a rezultaty działania widoczne dopiero w dłuższej perspektywie czasu. Dlatego też należy dążyć do takiego przedstawienia działań, aby interesariusze uznali i docenili znaczenie podejmowanych inicjatyw, co skutkować powinno udzielanym wsparciem.

Trzecim co do znaczenia ryzykiem wskazanym przez respondentów jest spadek dochodów z działalności (średnia 5,6832). Organizacje, które - tak jak przedsiębiorstwa społeczne - działają między sektorami, mimo że mają różne źródła finansowania (dotacje z różnych źródeł: od państwa, fundacji, firm, prywatnych sponsorów itd. oraz środki wypracowane z działalności rynkowej), to trudno jednoznacznie przewidzieć ich wysokość, strumienie i strukturę. Wielość potencjalnych źródeł finansowania jest zarówno szansą, jak i zagrożeniem dla ich funkcjonowania [Moore, 2000, s. 183-186]. Przykładowo, początkowa faza rozwoju spółdzielni socjalnych wiąże się ze znacznych uzależnieniem funkcjonowania od wysokości uzyskanej dotacji ze środków publicznych i sposobu jej wykorzystania. Największym ryzykiem dla działalności jest moment, w którym organizacji kończy się dotacja i musi polegać tylko na środkach wypracowanych z działalności rynkowej. Wskazane wcześniej ryzyka personalne mogą w tym momencie kumulować się i negatywnie wpływać na poziom dochodów z działalność i przyczynić się do zaprzestania działalności. Aby obniżyć wskazane ryzyko zarządzający muszą być w stanie identyfikować, analizować i interpretować wskaźniki wyników finansowych, jednocześnie pamiętając o priorytetowym znaczeniu celów społecznych. Muszą także w proaktywny sposób podchodzić do kwestii posiadanych zasobów finansowych i konfigurować je odpowiednio do potrzeb i realiów organizacji [Wronka-Pośpiech i inni, 2017].

Czwartym i piątym w hierarchii subiektywnie postrzeganych przez respondentów zagrożeń dla działalności przedsiębiorstw społecznych są niedotrzymanie lub naruszenie warunków umowy (średnia 5,4783) oraz odpowiedzialność ponoszona za jakość towaru/usługi (średnia 5,5590). Czynniki te są mocno powiązane z pierwszym najważniej- 
szym czynnikiem ryzyka, jakim jest czynnik ludzki w organizacji i można je różnorodnie interpretować. Na przykład jako obawę przed tym, że poziom zaangażowania pracowników w proces pracy będzie na tyle niski, że nie zostaną zrealizowane zadania, na realizację których podpisana została umowa (bądź praca zostanie wykonana w dłuższym czasie lub na poziomie niższym niż oczekiwany przez zlecającego). Może to skutkować niechęcią do zlecenia organizacji następnych zadań. Drugim potencjalnym zagrożeniem związanym w tej grupie czynników jest kwestia akceptacji przez zatrudnionych warunków pracy w organizacji. Często wyobrażenia zatrudnionych na temat potencjalnych dochodów oraz powierzonych do realizacji zadań są niekompatybilne z rzeczywistością i tym, czego oczekują. W skrajnych przypadkach konsekwencją takich zachowań może być brak akceptacji dla organizacji oraz podejmowanie działań oportunistycznych.

Tabela 2. 10 najważniejszych czynników ryzyka w przedsiębiorstwach społecznych - Polska

\begin{tabular}{|c|l|c|}
\hline $\begin{array}{c}\text { Numer } \\
\text { czynnika }\end{array}$ & \multicolumn{1}{|c|}{ Nazwa czynnika ryzyka } & $\begin{array}{c}\text { Średnia } \\
\text { ważona }\end{array}$ \\
\hline 3 & Brak zaangażowania się pracowników w działania organizacji & 6,2298 \\
\hline 11 & Utrata dobrej reputacji i/lub wyrobionej marki & 5,7081 \\
\hline 21 & Spadek dochodów z działalności & 5,6832 \\
\hline 17 & Niedotrzymanie lub naruszenie warunków umowy przez organizację & 5,4783 \\
\hline 15 & Odpowiedzialność ponoszona za jakość towaru/usługi & 5,5590 \\
\hline 23 & Niekorzystne zmiany sytuacji na rynku (zmieniające się warunki rynkowe) & 5,1801 \\
\hline 12 & Działania na szkodę klientów & 5,5342 \\
\hline 18 & $\begin{array}{l}\text { Niedotrzymanie lub naruszenie warunków umowy przez podmioty, z którymi współpracuje organizacja } \\
\text { (partnerów) }\end{array}$ & 5,3292 \\
\hline 8 & Kradzież zarobionych środków pieniężnych & 5,0124 \\
\hline 19 & Utrata środków pomocowych & 5,0497 \\
\hline
\end{tabular}

Źródło: wyniki badań własnych.

W opinii respondentów zagrożeniem dla rozwoju i trwania przedsiębiorstw społecznych są także niekorzystne zmiany sytuacji na rynku (warunki rynkowe) (średnia 5,1801), które oznaczają obniżenie popytu na dobra i usługi oraz większą konkurencję podmiotów, które dotychczas operowały w danym segmencie rynku. Problemem przedsiębiorstw społecznych jest to, że - z uwagi na poziom kapitału ludzkiego osób w nich zatrudnionych - mają one trudność w szybkiej adaptacji do zmieniających się warunków otoczenia i w ostrym konkurowaniu z innymi organizacjami o zasoby. Jest to szczególnie trudne na małych lokalnych rynkach, gdzie fundamentalna idea przedsiębiorstw spo- łecznych, polegająca na kreowaniu działań prozatrudnieniowych wśród osób zmarginalizowanych na rynku pracy i poprzez to tworzenia wartości publicznej/społecznej, nie do końca jest wspierana poprzez wybory konsumentów. Klienci częściej poszukują jednostkowo tańszej i lepszej jakości usługi/ produktu, niż skupiają się na kreowaniu prospołecznego rynku pracy.

Kolejnym czynnikiem identyfikowanym jako ryzyko dla działalności przedsiębiorstw społecznych są działania na szkodę klientów (średnia 5,5342), które można interpretować jako konsekwencję nie do końca prawidłowego zrozumienia zawartości zadań powierzonych do realizacji. Zamierzone dzia- 
łania na szkodę zdarzają się raczej rzadko, podczas gdy niezamierzone występują częściej i z reguły są konsekwencją psychospołecznego stanu pracownika. To ostatnie jest szczególnie widoczne w tych organizacjach, które zatrudniają osoby z dysfunkcjami psychicznymi.

Wybór kolejnego czynnika ryzyka, jakim jest niedotrzymanie lub naruszenie warunków umowy przez podmioty, z którymi współpracuje organizacja (partnerów) (5,3292), jest podyktowany specyfiką działania przedsiębiorstw społecznych oraz potrzebą pozyskiwania instytucjonalnego wsparcia przez organizacje i podmioty, z którymi współpracują (instytucje finansujące, klienci, władze publiczne, grupy nacisku, społeczności lokalne, prywatni darczyńcy, obywatele, wolontariusze, inne przedsiębiorstwa społeczne czy nawet organizacje typu for profit). Ponieważ funkcjonowanie przedsiębiorstw społecznych w dużej mierze zależy od możliwości zachowania płynności finansowej co z uwagi na przewagę celów społecznych w działalności nie jest łatwym zadaniem niezbędny jest życzliwy stosunek organizacji współpracujących do okresowych trudności przedsiębiorstw społecznych. Dlatego też umiejętne zarządzanie relacjami z partnerami może wpłynąć na rozwój organizacji [Frączkiewicz-Wronka, 2010; Frączkiewicz-Wronka, 2012.]

Kolejnym czynnikiem identyfikowanym jako ryzyko jest kradzież zarobionych środków pieniężnych (średnia 5,0124). Wybór tego czynnika podyktowany jest tym, że większość przedsięwzięć polegających na sprzedaży produktów lub usług narażona jest na ryzyko związane z kradzieżą zarobionych środków. To ryzyko jest tym większe, im trudniejszy jest kontakt pracownika przedsiębiorstwa z klientami. Utrudnienia w kontakcie mogą wynikać z niższych kompetencji społecznych jako następstwa dysfunkcji psychicznych lub fizycznych.
Dziesiątym czynnikiem ryzyka wskazanym przez respondentów jest utrata środków pomocowych (średnia 5,0497). W ostatnich latach w Polsce zanotowano gwałtowny wzrost liczby przedsiębiorstw społecznych (głównie spółdzielni socjalnych), co jest konsekwencją decyzji o finansowaniu działań związanych z realizacją idei aktywnej polityki społecznej (APS) przez państwa członkowskie UE w ramach funduszy unijnych. Ustawodawca, dążąc do wzmacniania kompetencji na rynku pracy, określił czas finansowego wsparcia działalności przedsiębiorstw społecznych na okres jednego roku. Po pierwszym roku działalności z dotacją można uzyskać dodatkowe wsparcie pomostowe, które ma ułatwić spółdzielni socjalnej pokrycie obligatoryjnych opłat ponoszonych w pierwszym okresie prowadzenia przez nią działalności. Po tym okresie organizacja powinna stać się samodzielna i samowystarczalna finansowo. Dotychczasowe statystyki jednoznacznie pokazują, że nie zawsze się tak dzieje. W związku w tym znaczna część organizacji zaczyna mieć kłopoty na rynku, które często kończą się koniecznością zaprzestania działalności. Brak dalszego wsparcia i niewytworzone w ramach organizacji umiejętności funkcjonowania w paradygmacie rynkowym są dużym problemem zarówno na poziomie indywidualnym (ponieważ doprowadzają do tego, że osoby które pracowały w przedsiębiorstw społecznych mogą po raz następny utracić pracę), jak i na poziomie społeczności lokalnej (ponieważ zwiększenie się grupy osób bezrobotnych skutkuje większymi nierównościami dochodowymi, brakiem spójności i wzrostem problemów związanych z dysfunkcjami społecznymi w środowisku zamieszkania).

W przypadku Hiszpanii znaczenie 10 wskazanych czynników krytycznych zostało zinterpretowane przez ekspertów centrum badawczego MIK. Niektóre z czynników są znane w środowisku zarządzających i badaczy, inne z kolei są słabo rozpoznawalne i wymagają 
dalszych badań oraz zwiększenia próby celem prawidłowej interpretacji wyników. W tabeli 3 przedstawiono 10 najważniejszych postrzeganych przez hiszpańskich respondentów ryzyk.

\section{Tabela 3. 10 najważniejszych czynników ryzyka w przedsiębiorstwach społecznych - Hiszpania}

\begin{tabular}{|c|l|c|}
\hline Numer czynnika & \multicolumn{1}{|c|}{ Nazwa czynnika ryzyka } & Średnia ważona \\
\hline 3 & Brak zaangażowania się pracowników w działania organizacji & 5,7911 \\
\hline 21 & Spadek dochodów z działalności & 5,7342 \\
\hline 19 & Utrata środków pomocowych & 5,7215 \\
\hline 23 & Niekorzystne zmiany sytuacji na rynku (zmieniające się warunki rynkowe) & 5,6835 \\
\hline 15 & Odpowiedzialność ponoszona za jakość towaru/usługi & 5,1709 \\
\hline 11 & Utrata dobrej reputacji i/lub wyrobionej marki & 5,0380 \\
\hline 20 & Utrata innych dochodów systemowych dochodów np. dotacji & 5,0000 \\
\hline 9 & Utrata informacji kluczowych dla działania organizacji & 4,6962 \\
\hline 18 & Niedotrzymanie lub naruszenie warunków umowy przez podmioty, z którymi współpracuje & 4,5886 \\
\hline 13 & Drganizacja (partnerów) & 4,4747 \\
\hline
\end{tabular}

Źródło: wyniki badań własnych.

Najważniejszym czynnikiem ryzyka według hiszpańskich respondentów jest brak zaangażowania się pracowników w działania organizacji (średnia: 5,7911). Jest to niezwykle istotny czynnik, ponieważ brak motywacji pracowników może sygnalizować nieefektywność kultury organizacyjnej lub brak zrozumienia danej kultury organizacyjnej przez pracowników. Analizując historię ruchu spółdzielczego Mondragon należy podkreślić, iż motywacja, zaangażowanie, entuzjazm, rozwinięty kapitał społeczny i spójność społeczna były źródłem sukcesu działania spółdzielni w pierwszych latach jej działania oraz w okresie recesji [Fernández, 2014]. Eksperci MiK podkreślają, że brak zaangażowania pracowników może być skutkiem wysokiej pewności zatrudnienia członków spółdzielni (jest to konsekwencją m.in. stałych umów o pracę ze względu na członkostwo w spółdzielni, specyficznych przepisów prawnych dotyczących ochrony pracowników czy specjalnego program relokacji pracowników w okresie ryzyka lub kryzysu). Paradoksalnie, trwałość zatrudnienia powinna wpływać pozytywnie na poczucie bezpieczeństwa pracowników, ich wysoką motywację oraz zaangażowanie w działanie spółdzielni, natomiast według opinii ekspertów MiK wpływa ona na spadek motywacji i niechęć do rozwoju wśród pracowników.

Kolejnych sześć czynników w ocenie ekspertów MiK posiada podobne podłoże historyczne oraz ekonomiczne i dlatego jest interpretowane w podobnym wymiarze. Do wspomnianych czynników należą: spadek dochodów (średnia:5,7342), utrata środkówpomocowych (średnia: 5,7215), niekorzystne zmiany sytuacji na rynku (średnia: 5,6835), odpowiedzialność za jakość towaru/usługi (średnia: 5,1709), utrata reputacji lub wyrobionej marki (średnia: 5,0380), oraz utrata innych dochodów systemowych np. dotacji (średnia: 5,0000). Do głównych przyczyn powyższych problemów należą: kryzys gospodarczy oraz bankructwo Fagor Electrodomésticos w 2013 r. Według danych Eurostat w okresie silnego kryzysu gospodarczego w 2009 r. inwestycje Mondragonu dramatycznie spadły [Arando i inni, 2010, s. 15], jednak w ogólnej ocenie spółdzielnie 
Mondragonu poradziły sobie na rynku znacznie lepiej niż inne przedsiębiorstwa w Hiszpanii, chociażby ze względu na program relokacji pracowników oraz ogólną zgodę członków spółdzielni na obniżenie wynagrodzenia o 8\% w okresie od kwietnia 2009 r. do marca 2010 r., co doprowadziło do utrzymania płynności finansowej Mondragonu oraz zwiększyło pulę środków na potencjalne inwestycje [ibidem, s. 14]. W 2010 r. w raporcie rocznym odnotowano zysk w wysokości 178 mln euro, co stanowiło trzykrotną wartość zysku z roku 2009. Warto zauważyć, że chociaż dzięki inwestycjom zagranicznym Mondragon stworzył ponad 1300 nowych miejsc pracy, to ogólne zatrudnienie cechował trend zniżkowy. Jest to po części konsekwencją tego, iż w 2013 r. doszło do bankructwa spółdzielni Fagor Electrodomésticos [Fernández, 2014], co naruszyło również sytuację finansową pozostałych spółdzielni, które w okresie ryzyka bankructwa jednej ze spółdzielni są zobowiązane do udzielenia jej wsparcia finansowego. Ponadto ograniczone środki pomocowe oraz niekorzystne zmiany na rynku wpływające na wielkość dochodów systemowych odbiły się na realnych możliwościach wsparcia kondycji istniejących spółdzielni. Upadek Fagor Electrodomésticos wywołał liczne negatywne komentarze w mediach, zarzucające modelowi spółdzielczemu Mondragon nieefektywność, choć wcześniej był on uznawany za przykład dobrych praktyk w obszarze ruchu spółdzielczego. Krytyka ta wpłynęła zarówno na ogólną reputację Mondragonu, jak i na reputację grupy Fagor oraz innych produktów wytwarzanych pod tą marką. Było to impulsem do zwrócenia większej uwagi na jakość oferowanych towarów i usług, a upadek jednej ze spółdzielni posłużył jako ostrzeżenie, że spółdzielnie w znacznej mierze zorientowane na aspekty społeczne powinny zadbać o efektywność w obszarze swojej aktywności biznesowej (w tym o jakość towarów i usług).

Pozostałe czynniki można sklasyfikować jako te związane z partnerami bizneso- wymi i siecią współpracy. Spośród ponad 250 partnerów biznesowych Mondragon blisko połowa to spółdzielnie socjalne, zatem ryzyko działań na szkodę podmiotów, z którymi współpracuje organizacja jest bardzo realne (średnia: 4,4747). Przykładem może być wspomniany wcześniej upadek jednej spółdzielni wpływający na reputację pozostałych. Ponadto tak rozbudowana sieć współpracy siłą rzeczy wiąże się z ryzykiem utraty kluczowych informacji (średnia: 4,6962) dla działania organizacji lub niedotrzymaniem/naruszeniem warunków umowy poprzez partnerów biznesowych (średnia: 4,5886).

\section{Podsumowanie}

Porównując wyniki badania przeprowadzonego w obu krajach można zauważyć, że większość czynników ryzyka, na które zwracali uwagę respondenci w Polsce jest zbieżna z tymi wskazanymi przez badanych ze spółdzielni Mondragonu (2 na 10 czynników pokrywa się całkowicie, 5 na 10 czynników ma zbliżone wartości). Można zatem zaryzykować stwierdzenie, że mimo wielu różnic prawnych oraz różnic w poziomie rozwoju ekonomii społecznej, czy nawet różnic kulturowych bądź rynkowych w badanych krajach, spółdzielnie Mondragonu - uznanego za lidera spółdzielczego w Europie - oraz spółdzielnie w Polsce zmagają się z podobnymi problemami. Wnioski płynące z przeprowadzonych badań stanowią wkład w badanie procesu zarządzania ryzykiem w podmiotach ekonomii społecznej oraz uświadamiają o konieczności reagowania na występujące zagrożenia bez względu na poziom rozwoju podmiotu. Zestawienie lidera spółdzielczego w Europie oraz mniej rozwiniętych podmiotów w Polsce i wykazanie kilku zbieżnych krytycznych czynników ryzyka sygnalizuje, że zagrożenia podmiotów społecznych nie są jedynie wynikiem uwarunkowań kulturowych czy społecznych, ale dotyczą też samej istoty działalności podmiotów, która nawet w wymiarze 
międzykulturowym pozostaje taka sama. Porównane czynniki ryzyka $w$ obu badanych krajach podzielono na trzy kategorie: (1) kategoria oznaczona pogrubieniem to czynniki całkowicie pokrywające się $w$ rankingu; (2) kategoria oznaczona kursywa to czynniki, które nie zostały sklasyfikowane jako krytyczne $w$ jednym $z$ badanych krajów, a zatem brak czynnika $w$ rankingu $w$ danym kraju jest oznaczony jako '0'; oraz (3) pozostałe czynniki, które zajęły zbliżone miejsce $w$ rankingu (tabela 4).

Tabela 4. Czynniki ryzyka w Polsce i w Hiszpanii

\begin{tabular}{|c|l|c|c|}
\hline Lp. & \multicolumn{1}{|c|}{ Nazwa czynnika ryzyka } & $\begin{array}{c}\text { Pozycja } \\
\text { w rankingu - } \\
\text { Polska }\end{array}$ & $\begin{array}{c}\text { Pozycja } \\
\text { w rankingu - } \\
\text { Hiszpania }\end{array}$ \\
\hline 3 & Brak zaangażowania się pracowników w działania organizacji & $\mathbf{1}$ & $\mathbf{1}$ \\
\hline 21 & Spadek dochodów z działalności & 3 & 2 \\
\hline 19 & Utrata środków pomocowych & 10 & 3 \\
\hline 23 & Niekorzystne zmiany sytuacji na rynku (zmieniające się warunki rynkowe) & 6 & 4 \\
\hline 15 & Odpowiedzialność ponoszona za jakość towaru/usługi & $\mathbf{5}$ & $\mathbf{5}$ \\
\hline 11 & Utrata dobrej reputacji i/lub wyrobionej marki & 2 & 6 \\
\hline 20 & Utrata innych dochodów systemowych dochodów np. dotacji & 0 & 7 \\
\hline 9 & Utrata informacji kluczowych dla działania organizacji & 0 & 8 \\
\hline 18 & $\begin{array}{l}\text { Niedotrzymanie lub naruszenie warunków umowy przez podmioty, z którymi współpracuje } \\
\text { organizacja (partnerów) }\end{array}$ & 8 & 9 \\
\hline 13 & Działania na szkodę podmiotów, z którymi współpracuje organizacja (partnerów) & 0 & 10 \\
\hline 17 & Niedotrzymanie lub naruszenie warunków umowy przez organizację & 4 & 0 \\
\hline 12 & Działania na szkodę klientów & 7 & 0 \\
\hline 8 & Kradzież zarobionych przez nas środków pieniężnych & 9 & - \\
\hline
\end{tabular}

Źródło: wyniki badań własnych.

Powyższa klasyfikacja wskazuje na brak zaangażowania się pracowników w działania organizacji oraz odpowiedzialność ponoszoną za jakość towaru/usługi jako czynniki wysokiego ryzyka w obu krajach. Czynniki takie jak niedotrzymanie lub naruszenie umowy przez organizację, działania na szkodę klienta lub kradzież zarobionych środków pieniężnych zostały uznane za istotne tylko w spółdzielniach socjalnych w Polsce. Z kolei utrata innych dochodów systemowych np. dotacji, utrata informacji kluczowych dla działania organizacji oraz działania na szkodę podmiotów, z którymi współpracuje organizacja zostały uznane jako istotne tylko w badanych organizacjach w Kraju Basków w Hiszpanii. Dwa ostatnie czynniki związane są z wysokorozwiniętą siecią współpracy, a ich niewskazanie w polskich warunkach może sygnalizować brak lub niski poziom rozwoju zjawiska partnerowania oraz tworzenia sieci współpracy w Polsce [Starnawska, 2014]. Jednocześnie może być to wskazówką do identyfikacji potencjalnego zagrożenia dla zarządzających podmiotami społecznymi w Polsce i planujących w przyszłości rozbudowanie partnerstwa pomiędzy istniejącymi podmiotami w warunkach polskich. Pozostałe czynniki, takie jak spadek dochodów z działalności, utrata środków pomocowych, niekorzystne zmiany sytuacji na rynku, utrata dobrej reputacji i/lub wyro- 
bionej marki, niedotrzymanie lub naruszenie warunków umowy przez podmioty, z którymi współpracuje organizacja to czynniki uznane za krytyczne w obu krajach ze zbliżonym miejscem w rankingu.

Reasumując prowadzone rozważania zauważamy, że podmioty ekonomii społecznej - szczególnie polskie, działające w turbulentnym otoczeniu, z ograniczoną liczbą specjalistów i słabą wiedzą na temat realiów prawno-ekonomicznych, w obliczu konieczności sprostania wielu złożonych wymagań muszą umiejętnie się dostosowywać do ciągłych zmian. Obecna sytuacja wymaga od zarządzających nie tylko większej innowacyjności, ale także przyjmowania postawy proaktywnej, tym bardziej biorąc pod uwagę pozytywny związek orientacji przedsiębiorczej z efektywnością organizacji [Wronka-Pośpiech, 2016, s. 740-742]. Dlatego identyfikacja ryzyk w działalności przedsiębiorstwa społecznego powinna być jednym z podstawowych zadań osób zarządzających nimi. Powyższe stwierdzenie uznajemy za zasadne, bowiem zidentyfikowanie ryzyka pozwala na określenie obszarów, w których decyzje strategiczne muszą być wprowadzone, a także obszary, procedur i procesów, które wyma-

\section{Literatura}

Alonso J.M., Clifton J., Diaz-Fuentes D. (2015). „Did New Public Management Matter? An Empirical Analysis of the Outsourcing and Decentralization Effects on Public Sector Size", Public Management Review, Vol. 17, No. 5, s. 646-660.

Arando S., Feundlich F., Gago M., Jones D.C., Kato T. (2010). „Assessing Mondragon: Stability \& Managed Change in the Face of Globalization", William Davidson Institute Working Paper No. 1003, http://papers. ssrn.com/sol3/papers.cfm?abstract_id=1726449.

Arrow K.J. (1971). Essays it the Theory of Risk Bearing. Chicago: Markham, Chicago.

Asenova D., Stephen J., Bailey S.J., McCann C. (2015). „Public Sector Risk Managers and Spending Cuts: Mitigating Risks", Journal of Risk Research, Vol. 18, No. 5, s. 552-565. gają poprawy. Kwestie te mają kluczowe znaczenie, zwłaszcza dla przedsiębiorstw społecznych, które obecnie stoją w obliczu poważnych trudności związanych z oceną skuteczności ich działań. Identyfikacja ryzyka jest pierwszym krokiem do aktywnego zarządzania organizacjami. Analiza pojawiających się tendencji kieruje uwagę zarządzających na identyfikację zagrożeń, a umiejętność rozpoznawania ich ma szczególne znaczenie dla przedsiębiorców społecznych. Przeprowadzona analiza sprzyja procesowi dyfuzji wiedzy zarówno w przypadku czynników pokrywających się, jak i tych całkowicie rozbieżnych. Krytyczne czynniki ryzyka pokrywające się w obu krajach są wynikiem istoty działania podmiotów ekonomii społecznej, która pozostaje niezmienna bez względu na poziom rozwoju przedsiębiorstwa społecznego oraz kraj pochodzenia, a wykryte czynniki rozbieżne są wywołane innym kierunkiem rozwoju podmiotów ekonomii społecznej w badanych krajach, niemniej jednak mogą one stanowić wskazówkę dla zarządzających przy identyfikacji zagrożenia w momencie zmiany kursu rozwoju ekonomii społecznej w innych warunkach kulturowych.

Bennet P., Calman K., Curtis S., FischbacherSmith D. (2010). Risk Communication and Public Health. Oxford: Oxford University Press.

Borraz O. (2007). „Risk and Public Problems”, Journal of Risk Research, Vol. 10, No. 7, s. 941-957.

Carmen N., Dobrea C.R. (2006). „Adapting Risk Management Principles to the Public Sector Reforms", Administraţie şi Management Public, Vol. 6, s. 126-130.

Carroll R. (red.) (2009). Risk Management Handbook for Health Care Organizations. Hoboken: John Wiley \& Sons.

Chen Ch.A., Bozeman B. (2012). "Organizational Risk Aversion: Comparing The Public and Non-Profit", Public Management Review, Vol. 14, No. 3, s. 377-402.

Ciepielewska-Kowalik A., Pieliński B., Starnawska M., Szymańska A. (2015). „Social Enterprise in Poland: Institutional and Historical Context", ICSEM Working Papers, nr 11, Liege: The International Comparative Social Enterprise Models (ICSEM) Project. 
Dees J.D. (1998). The meaning of 'social entrepreneurship'. Centre for Advancement of Social Entrepreneurship (CASE), Fuqua School of Business, Duke University, Durham, www.fuqua.duke.edu/centers/ case/articles/0805/corner.

Defourny J., Develtere P. (2008). „Ekonomia społeczna - ogólnoświatowy trzeci sektor", w: J.J. Wygnański (red.), Przedsiębiorstwo społeczne - antologia kluczowych tekstów, Warszawa: FISE.

Defourny J., Develtere P. (2009). "The Social Economy: the Worldwide Making of a Third Sector", w: J. Defourny, P. Develtere, B. Fonteneau, M. Nyssens (red.), The Worldwide Making of the Social Economy. Innovations and Changes (s. 15-40). Leuven \& The Hague: Acco.

Drennan L., McConnell A. (2007). Risk and Crisis Management in the Public Sector. London: Routledge.

Drucker P. (1964). Managing for Results: Economic Tasks and Risk-taking Decisions. London: Heinemann.

Enterprising Non-Profits Program (2005). The Canadian Social Enterprise Guide.

Fernández J.R. (2014). A review of the key milestones in the co-operative group's history, http://www.mondragon-coorporation.com/wp-content/themes/ mondragon/docs/History-MONDRAGON-1956-2014. pdf.

Fone M., Young P.C. (2007). Managing Risks in Public Organizations. New York: Palgrave Macmillan.

Frączkiewicz-Wronka A. (2010). „Pomiar efektywności i interesariusze oraz ich znaczenie dla strategii organizacji publicznych", w: R. Krupski (red.), Zarzqdzanie strategiczne. Podstawowe problemy (s. 283301). Wałbrzych: Wydawnictwo Wałbrzyskiej Wyższej Szkoły Zarządzania i Przedsiębiorczości.

Frączkiewicz-Wronka A. (2012). „Analiza interesariuszy jako metoda wspierająca formułowanie strategicznych zamierzeń w organizacji", w: R. Krupski (red.), Metody badań problemów zarządzania strategicznego (s. 269-292). Wałbrzych: Wydawnictwo Wałbrzyskiej Wyższej Szkoły Zarządzania i Przedsiębiorczości.

Grewiński M., Karwacki A. (red.) (2015). Innowacyjna polityka społeczna. Warszawa: Wydawnictwo WSP im. J. Korczaka.

Grzybowski W. (1974). Teoria gospodarowania w warunkach niepewności w zarysie. Lublin: Uniwersytet Marii Curie-Skłodowskiej w Lublinie.

Grzybowski W. (1976). Ryzyko w procesie podejmowania decyzji. Studium teoretyczno-badawcze. Lublin: Uniwersytet Marii Curie-Skłodowskiej w Lublinie.

Grzybowski W. (1991). Rachunek ekonomiczny w przedsiębiorstwie w warunkach ryzyka. Lublin: Uniwersytet Marii Curie-Skłodowskiej w Lublinie.

Grzybowski W. (1994). Przedsiębiorczość i ryzyko w gospodarce rynkowej. Lublin: Uniwersytet Marii Curie-Skłodowskiej w Lublinie.

Grzybowski W. (1995). Przedsiębiorczość, niepewność, zysk. Lublin: Uniwersytet Marii Curie-Skłodowskiej w Lublinie.
Haltiwanger G., Landaeta R.E., Pinto C.A., Tolk A. (2010). „Understanding the relationship between risk management and knowledge management", International Journal of Knowledge Management Studies, Vol. 4, No. 3, s. 281-300

Herbst J. (2008). „Polski trzeci sektor w świetle teorii przedsiębiorstwa społecznego", w: Od trzeciego sektora do przedsiębiorczości społecznej - wyniki badań ekonomii społecznej w Polsce (s. 124-142). Warszawa: Stowarzyszenie Klon/Jawor

Hoogendoorn B, van der Zwan P.W., Thurik A.R. (2011). "Social Entrepreneurship and Performance: The Role of Perceived Barriers and Risk", ERIM report series research in management Erasmus Research Institute of Management (No. ERS-2011-016-ORG), http:// hdl.handle.net/1765/25538.

IRM (2004). A Risk Management Standard. London.

Klimczak M.K. (2009). „Wdrożenie zarządzania ryzykiem w jednostkach sektora finansów publicznych", Przegląd Organizacji, nr 5, s. 23-26.

Klimczak M.K., Pikos A.M. (2010). „Percepcja ryzyka a kontrola zarządcza w sektorze publicznym", Przegląd Organizacji, nr 12, s. 27-30.

Kolluru R.V., Bartell S.M., Pitblado R.M., Stricoff R.S. (1996). Risk Assessment and Management Handbook: For Environmental, Health and Safety Professionals. New York: McGraw-Hill.

Krajowy Program Rozwoju Ekonomii Społecznej (2014). Monitor Polski, poz. 811, tom 1.

Kurleto M. (2015). „An Application of the Corporate Company Models for Social Enterprise (with Special Emphasis on Polish Conditions)", European Journal of Service Management, nr. 15, s. 57-85.

Leadbeater C. (1998). The rise of Social Entrepreneur. London: Demos.

Lipka A. (2002). Ryzyko personalne. Szanse i zagrożenia zarzadzania zasobami ludzkimi. Warszawa: Poltext. Ministerio de Empleo y Seguridad Social (2014). Avance.-Resumen Situacion Empresas de Economia Social y Sus Trabajadores en Situacion de Alta en la Seguridad Social, http://www.empleo.gob.es/es/ estadisticas/.

Moore M. (2000). „Managing for value: organizational strategy in for-profit, non-profit, and governmental organizations", Nonprofit and Voluntary Sector Quarterly, No. 29, s. 189-195

Peredo A.M., McLean M. (2006). "Social entrepreneurship: A critical review of the concept", Journal of World Business, Vol. 41, No. 1, s. 56-65.

Raport, Komisja Europejska (2015a). A map of social enterprises and their eco-systems in Europe. Brussels: European Commission Directorate General for Employment, Social Affairs and Inclusion, http:// ec.europa.eu/social/main.jsp?langld=en\&catld=89\& newsld=2149.

Raport, Komisja Europejska (2015b). A map of social enterprises and their eco-systems in Europe. Country Reports: Spain. Brussels: European Commission Directorate General for Employment, Social Affairs and 
Inclusion, http://ec.europa.eu/social/main.jsp?langld $=e n \& c a t l d=89 \&$ newsld $=2149$.

Raport, Komisja Europejska (2015c). A map of social enterprises and their eco-systems in Europe. Country Reports: Poland. Brussels: European Commission Directorate General for Employment, Social Affairs and Inclusion, http://ec.europa.eu/social/main.jsp?la ngld=en\&catld=89\&newsld=2149.

Shaw E., Carter S. (2007). "Social entrepreneurship: Theoretical antecedents and empirical analysis of entrepreneurial processes and outcomes", Journal of Small Business and Enterprise Development, Vol. 14, No. 3, s. 418-434.

Smith D., McCloskey J. (1998). „Risk and Crisis Management in the Public Sector: Risk Communication and the Social Amplification of Public Sector Risk", Public Money \& Management, Vol. 18, No. 4, s. 41-51.

Starnawska M. (2014). „Zachowanie poprzez sieciowanie w przedsiębiorczości społecznej w odpowiedzi na trudne otoczenie instytucjonalne - przypadek 5 spółdzielni socjalnych", Problemy Zarządzania, Vol 12, No 4(48), t. 2, s. 97-116.

Starnawska M. (2016). „Między wspólnotą a biznesem - system rządzenia w przedsiębiorstwie społecznym - studia przypadku", Przegląd Organizacji, nr 1, s. 28-36.

Szudy M. (2013). "Model zatrudnienia w korporacji spółdzielczej Mondragón", w: S. Swadźba, D. Bochańczyk-Kupka (red.), Systemy gospodarcze i ich ewolucja. Aspekty mikro i mezoekonomiczne. Studia ekonomiczne, nr 156, Katowice: Uniwersytet Ekonomiczny w Katowicach, s. 127-135.

Tan W.L., Williams J., Tan T.M. (2005). „Defining the 'social' in 'social entrepreneurship': Altruism and entrepreneurship", The International Entrepreneurship and Management Journal, Vol. 1, No. 3, s. 353-365.

Tworek P. (2014). „Behavioural aspects of risk management in investment processes in construction", w: M. Čulik (red.), Managing and Modelling of Financial Risks (Part III), Proceedings from $7^{\text {th }}$ International Conference. Ostrava: VŠB - Technická Univerzita, s. 832-839.

Tworek P. (2015a). „Wykorzystanie listy kontrolnej w zarządzaniu ryzykiem w organizacjach publicznych", w: K.Z. Kapuścińska, S. Lachiewicz, M. Matejun (red.), Współczesne organizacje wobec wyzwań zarzq- dzania ryzykiem - aspekty poznawcze. Łódź: Wydawnictwo Politechniki Łódzkiej.

Tworek P. (2015b). „Public Risk Management (PRM)”, w: M. Čulik (red.), Financial Management of Firms and Financial Institutions. Part IV. Proceedings from 10th International Conference. Ostrava: VŠB - Technická Univerzita, s. 1340-1347.

Tworek P., Cziura P. (2017). „Wybrane problemy zarządzania ryzykiem w działalności przedsiębiorstw społecznych", Zeszyty Naukowe Politechniki Częstochowskiej, Zarzązanie (w druku).

Ustawa z dnia 27 kwietnia 2006 roku o spółdzielniach socjalnych (Dz.U. Nr 94, poz. 651 z późn. zm.).

Vincent J. (1996). „Managing Risk in Public Services: A Review of the International Literature", International Journal of Public Sector Management, Vol. 9, No. 2, s. 57-64.

Wieloletni regionalny plan działań na rzecz promocji i upowszechnienia ekonomii społecznej oraz rozwoju instytucji sektora ekonomii społecznej i jej otoczenia w województwie śląskim na lata 2012-2020 (2012). Katowice: Regionalny Ośrodek Pomocy Społecznej Województwa Śląskiego.

Wronka-Pośpiech M., Frączkiewicz-Wronka A., Laska K. (2017). „Risk Perception in the Activity of Social Enterprises", w: K. Raczkowski (red.), Risk Management in Public Administration, London: Palgrave Macmillan, s. 189-226.

Wronka-Pośpiech M. (2015). „Identyfikacja zależności pomiędzy orientacją przedsiębiorczą a sukcesem przedsiębiorstw społecznych - wyniki badań empirycznych", w: J. Brzóska, J. Pyka (red.), Zeszyty Naukowe Politechniki Śląskiej, Organizacja i Zarządzanie, z. 83, Gliwice: Wydawnictwo Politechniki Śląskiej, S. 735-746

Young P.C., Fone M. (2001). Public Sector Risk Management. Oxford: Butterworth-Heinemann.

Zahra S.A., Gedajlovic E., Neubaum D.O., Shulman J.M. (2009). „A typology of social entrepreneurs: Motives, search processes and ethical challenges", Journal of Business Venturing, Vol. 24, No. 5, s. 519-532.

Zahra S.A., Rawhouser H.N., Bhawe N., Neubaum D.O., Hayton J.C. (2008). "Globalization of social entrepreneurship opportunities", Strategic Entrepreneurship Journal, Vol. 2, No. 2, s. 117-131.

\section{The risk perception in social enterprises - the comparative study of Poland and Spain}

Summary: Social enterprises that inter alia address social exclusion are an innovative method of solving numerous social issues. The article aims at identifying the potential risk factors that influence the analysed entities performance. The research has been based on the model of 26 risk factors presented to the managers from Poland (160) and the Basque Country, Spain (158) for the multicultural approach purposes. The analyses have resulted in interpretation of the differences of the risk factors perception and its varied determinants, which is crucial in estimation of the potential obstacles in the organizational environment affecting the social enterprise effectiveness. The international context of the conducted research has elaborated on the risk management aspect throughout valuable knowledge share between the analysed countries, which enriches the dynamic but chaotic social economy development in Poland.

Keywords: risk, social services, social enterprises, co-operative, Mondragon. 


\section{Prawa autorskie i licencja / Copyright and License}

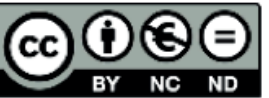

Artykuł opublikowano na licencji Creative Commons

Uznanie autorstwa - Użycie niekomercyjne - Bez utworów zależnych 3.0 Polska

http://creativecommons.org/licenses/by-nc-nd/3.0/pl/

This article is published under the terms of the Creative Commons

Attribution - NonCommercial - NoDerivs (CC BY-NC-ND 3.0) License

http://creativecommons.org/licenses/by-nc-nd/3.0/ 